\title{
Energy Efficient Air Conditioning System Using Geothermal Cooling-Solar Heating in Gujarat, India
}

\author{
Sneha Shahare ${ }^{1,2}$, T. Harinarayana ${ }^{1^{*}}$ \\ ${ }^{1}$ Gujarat Energy Research and Management Institute, PDPU Campus, Gandhinagar, India \\ ${ }^{2}$ School of Technology, PDPU, Gandhinagar, India \\ Email: "harinarayana@germi.res.in
}

Received 27 August 2015; accepted 24 January 2016; published 27 January 2016

Copyright (C) 2016 by authors and Scientific Research Publishing Inc.

This work is licensed under the Creative Commons Attribution International License (CC BY). http://creativecommons.org/licenses/by/4.0/

(c) (i) Open Access

\begin{abstract}
It is well known that one unit of electrical energy saved is equal to more than two units produced. One way of economizing the power is utilization of energy efficient systems at all locations. In the present study, the air conditioning system is analysed and an innovative way is suggested. We use natural low temperature of shallow sub surface $(1-3 \mathrm{~m})$ of the earth-geothermal cooling system. It is known that majority of the households and the apartment complexes in India have two tanks for water storage. One is the underground water sump and the other is the overhead water tank. In our study, we use these two water storage systems for space cooling during summer and also for heating during winter. The main aim of our paper is air-conditioning of the space in an economic way to save electricity. It is based on a simple idea of transferring the low temperature from underground water sump to the room in the house using water as a mode of transport. Since India is a tropical country located at low latitude, most of the year, the air temperature is high and demands space cooling. However, for a couple of months during severe winter months (Dec.-Jan.) at Ahmedabad, heating of the space is required. For heating the space, we suggest to use the wellknown solar water heater. Effective use of heat exchanger is shown through computation, modelling schemes and lab experiment. We recommend geothermal cooling for 10 months in a year and solar hot water system during 2 months of winter. It is observed that the ambient air temperature of $35^{\circ} \mathrm{C}-40^{\circ} \mathrm{C}$ in the room can be brought down to $26^{\circ} \mathrm{C}$ without much consumption of electricity. In a similar manner, the room temperature at night $\left(13^{\circ} \mathrm{C}\right)$ during winter in Ahmedabad can be increased to $27^{\circ} \mathrm{C}$ through circulation of water from solar water heater in the heat exchanger.
\end{abstract}

\section{Keywords}

Energy Efficiency, Geothermal Cooling, Air Conditioning, CFD, Thermal Comfort, Earth Water Heat

${ }^{*}$ Corresponding author.

How to cite this paper: Shahare, S. and Harinarayana, T. (2016) Energy Efficient Air Conditioning System Using Geothermal Cooling-Solar Heating in Gujarat, India. Journal of Power and Energy Engineering, 4, 57-71.

http://dx.doi.org/10.4236/jpee.2016.41004 


\section{Exchanger}

\section{Introduction}

As the demand for power is growing in the country, production should also need to increase to meet the demand. For comfortable living, all human beings require a near constant air flow with a temperature of about $25^{\circ} \mathrm{C}$ to $28^{\circ} \mathrm{C}$ with $25 \%$ - 50\% of humidity. For this purpose, historically we have been developing and using many air flow equipment. It all starts with a simple hand fan and later a mechanised fan followed by air coolers and the latest one is the air conditioning equipment (or simply AC) to achieve the cooling effect. Similarly, (for heating the space) burning of wood, coal in older days is now changed to electric heaters. Both the equipment-air conditioner and electric heater are energy intensive equipment and require large amount of power. We need to economise the power with innovative ideas in such a way that minimum amount of energy can be used without compromising on the comfort.

In recent years, India becomes a power hungry nation [1]. In one estimation, it is observed that demand for power will grow from the existing $255 \mathrm{GW}$ (2014) to $903 \mathrm{GW}$ (2024) assuming 9\% annual increase in the usage of power [2]. The increase in power demand is now at a faster rate than before as more people have started using the available electrical and electronic gadgets for comfort. Due to less power production, power failures, power cuts become a common phenomenon in many states of India. Another problem in India is due to power losses. It is reported that the T\&D losses are about 20\% - 30\% [3] [4]. It is known that the cost of one unit of electrical energy utilized is equal to the cost of more than 2 units of electricity generated [5]. In this scenario, saving energy is of utmost important. Several attempts are being made to improve the efficiency of various electrical, electronic and mechanical equipment at all places. In such a scenario, the time has come to develop energy efficient air conditioning system.

In the following, various equipments presently being used in various locations, both in rural and urban sectors, are briefly described. If we study various air flow equipment, normal hand fans and electric fans cannot give great comfort as its role is limited. They only push the air from one place to the other. It has no mechanism to reduce the temperature in an area. Air coolers are more efficient than normal electric fans. It contains the water circulation in a small area and thus reduces the temperature of the ambient air. This cooled air will be pushed from a small enclosed area to the room and thus reduces the room temperature. The commercially available air coolers in recent years have two basic electric motors. One motor pumps the water from lower level to the upper level of about 3 to 4 feet. Another motor drives the air from inside to outside, in a similar fashion as that of a normal electric fan. The air conditioning system has a compressor as additional equipment. The air from the atmosphere is compressed in the compressor and released into the atmosphere in a controlled fashion. This way the compressed air under high pressure when released to the normal atmospheric pressure, expands and thus the temperature of the air decreases. This is due to the well-known phenomena called "Joule Thomson Effect". In recent years, split air conditioning equipment has become more popular. In this system, there are two equipments. One is the compressor unit with air intake and another is the air blower with controllers. It is pertinent to say that the air conditioning equipment, although more comfortable than all other equipment, consumes large power. Traditional air cooler, although give comfort by reducing air temperature, it has a problem of humidity. It increases the moisture in the air. After a period of use, the discomfort level increases due to moisture effect on the skin. More importantly, it is not effective in high humid regions such as coastal regions. In such a scenario, the time has come to develop efficient, low energy equipment for thermal comfort.

Thermal comfort is that condition of the mind that expresses satisfaction with thermal environment [6]. An individual experiencing thermal comfort is the one satisfied and feels comfortable with his surrounding environment. One can determine the thermal comfort zone for Indian climate in terms of dry bulb temperature and relative humidity. Indian Bureau of Standards has suggested thermal comfort range for air-conditioned buildings to be from $23^{\circ} \mathrm{C}$ to $26^{\circ} \mathrm{C}$ and relative humidity to be between $25 \%$ to $50 \%$ and air movement is between $0.15 \mathrm{~m} / \mathrm{s}$ to $0.50 \mathrm{~m} / \mathrm{s}$. In 2004, lower margin of relative humidity has expanded the comfort temperature. When the relative humidity is as low as $10 \%$, the suggested comfort range is from $25^{\circ} \mathrm{C}$ to $28^{\circ} \mathrm{C}$, whereas for the relative humidity of $55 \%$, the suggested comfort range varies from $24^{\circ} \mathrm{C}$ to $27^{\circ} \mathrm{C}$ [7]. Various researches have been carried out in search of the correct thermal comfort range for warm and humid climate such as Indian climate. Table 1 
shows the human reaction to the condition of different air speed. Range of acceptable speed of air level is from 0.2 to $0.5 \mathrm{~m} / \mathrm{s}$ [8].

\section{Basic Concepts of the Proposed System}

Here we propose to use geothermal cooling system to reduce the temperature of space. Figure 1 shows the concept diagram. The proposed concept is simple. We all know that the temperature below the earth increases as the depth increases. However, at shallow depth of about 3 - $5 \mathrm{~m}$ (10 to 15 feet), the temperature of the soil decreases compared to the ambient temperature. This can be seen from the temperature depth profile shown in Figure 2. This decrease in temperature is about $3^{\circ} \mathrm{C}-5^{\circ} \mathrm{C}$ less than the surface temperature.

Additionally, the temperature retaining capacity of water is more than the air and land surface. The low temperature of water in the sump is pumped up using an electric motor to thermally insulated storage water tank on the roof and stored. As per the requirement, this cold water will reach the underground water sump again with a slow flow rate through gravity without any power via the heat exchanger in the room. Now let us examine the temperature variation in different seasons in Ahmedabad region. For example, Table 2 shows ambient temperature and variation of soil temperature around the year for Ahmedabad region at different depths of 0 to $3 \mathrm{~m}$ [9].

Table 1. Human reaction to different air speed.

\begin{tabular}{cc}
\hline Speed of air & Feeling of person \\
\hline$<0.1 \mathrm{~m} / \mathrm{s}$ & Stuffy \\
to $0.2 \mathrm{~m} / \mathrm{s}$ & Unnoticed \\
to $0.5 \mathrm{~m} / \mathrm{s}$ & Pleasant \\
to $1.0 \mathrm{~m} / \mathrm{s}$ & Awareness \\
to $1.5 \mathrm{~m} / \mathrm{s}$ & Draughty \\
$>1.5 \mathrm{~m} / \mathrm{s}$ & Annoying \\
\hline
\end{tabular}

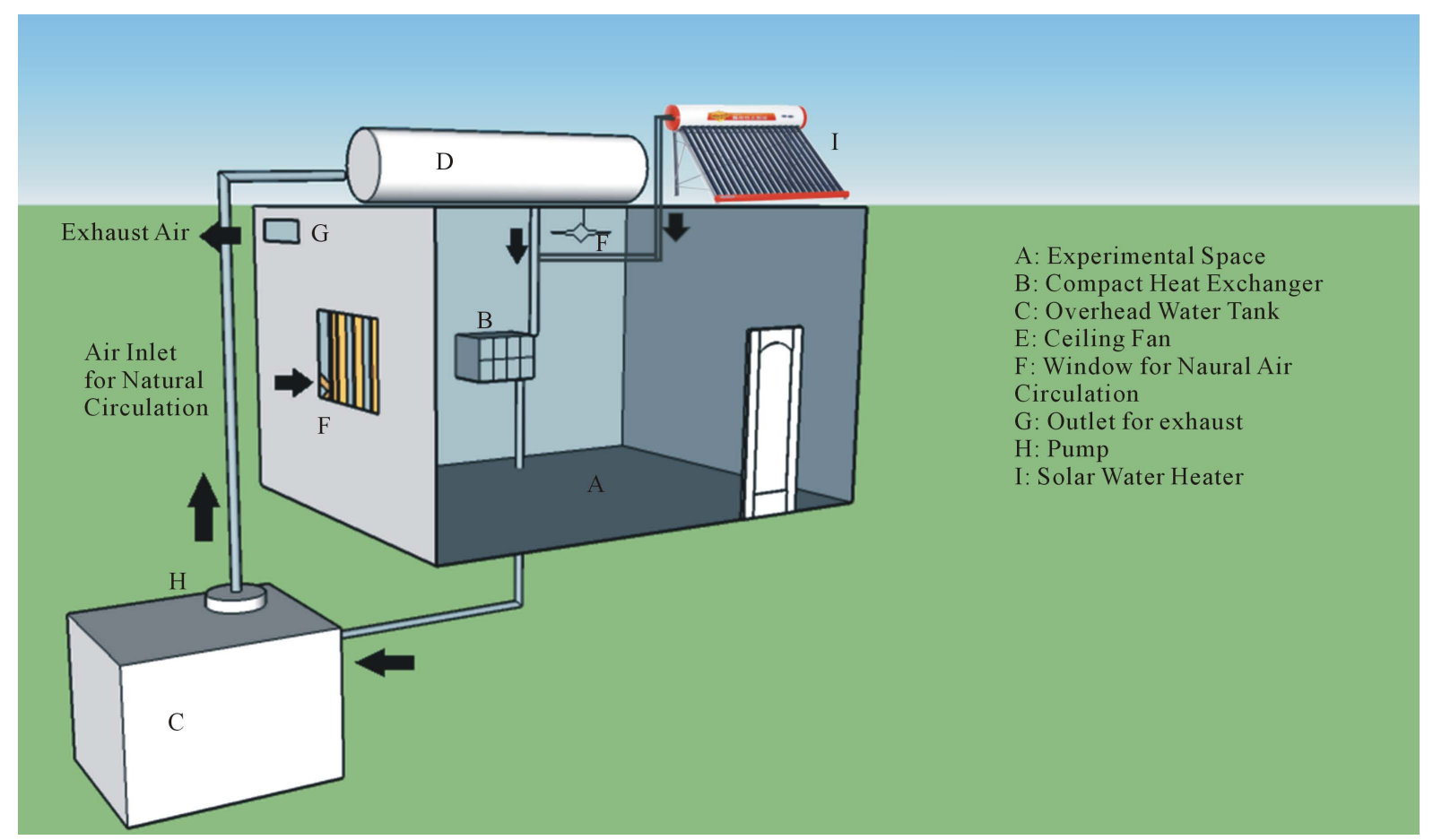

Figure 1. Schematic diagram showing the concept used in the present study. Here underground cooled water is pumped to the overhead tank. 


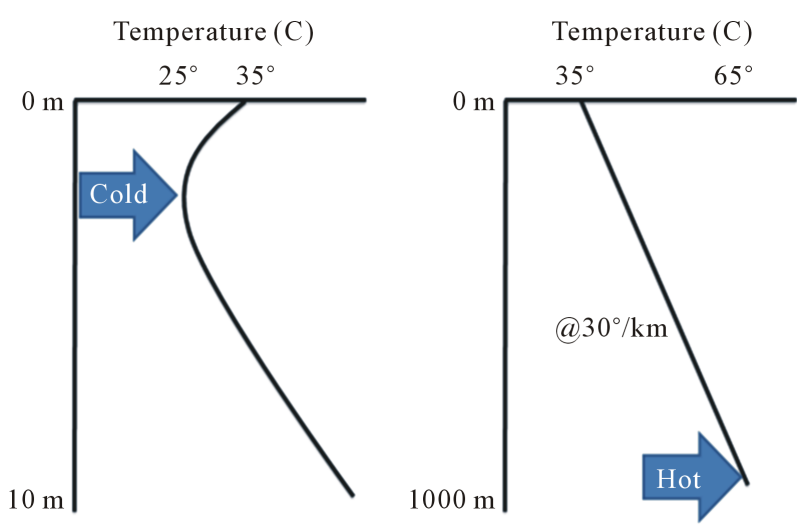

Figure 2. Schematic diagram showing a typical phenomenon near the surface of the earth at $0-10 \mathrm{~m}$ and also for 0 - 1000 $\mathrm{m}$ depth.

Table 2. Mean Temperature variation around the year for Ahmedabad region.

\begin{tabular}{cccccc}
\hline Month & Ambient temp. $\left({ }^{\circ} \mathrm{C}\right)$ & \multicolumn{3}{l}{ Soil temperature $\left({ }^{\circ} \mathrm{C}\right)$ at depth } \\
\hline Date & $1 \mathrm{~m}$ & $0 \mathrm{~m}$ & $-1 \mathrm{~m}$ & $-2 \mathrm{~m}$ & $-3 \mathrm{~m}$ \\
\hline January 15 & 20.0 & 15.5 & 20.9 & 22.5 & 24.2 \\
February 15 & 23.1 & 17.1 & 20.9 & 22.0 & 25.2 \\
March 15 & 27.4 & 26.4 & 22.5 & 22.3 & 25.8 \\
April 15 & 31.6 & 35.6 & 25.8 & 23.8 & 26.6 \\
May 15 & 33.8 & 34.8 & 28.8 & 26.4 & 29.8 \\
June 20 & 31.8 & 34.8 & 30.2 & 28.1 & 28.5 \\
July 20 & 28.7 & 31.9 & 30.0 & 28.4 & 28.9 \\
August 20 & 28.0 & 26.3 & 25.6 & 26.3 & 25.6 \\
September 15 & 28.0 & 27.5 & 26.5 & 26.6 & 26.1 \\
October 11 & 27.7 & 27.6 & 26.0 & 26.7 & 24.3 \\
November 16 & 24.3 & 24.5 & 23.9 & 25.2 & 24.4 \\
December 13 & 21.0 & 20.1 & 22.2 & 3.2 & 2.8 \\
\hline
\end{tabular}

Note: Values are mean of 24 hours.

In such a scenario, one can transport the heat from one location to the other and can decrease the temperature of space in any room as per the requirement. As discussed before, we would like to pump the water from the sump to the thermally insulated overhead water tank. For exchange of low temperature of water in the heat exchanger with the ambient air temperature, a ceiling fan is used. It will circulate the hot air of the room to exchange with the low heat in the exchanger and reduces the temperature of the air. This way, after a short period of 1 to 2 hours, the entire room reaches the equilibrium state and reaches the temperature close to that of the heat exchanger.

Thus our concept is new as compared to the popularly existing [10]-[16] geothermal cooling models. In the literature, various designs are suggested [17]-[23] that require prior planning before the construction of houses or buildings. The old buildings are also being done by some geothermal cooling agencies by occupying large open area space, digging and piping network in the underground. There is a lot of research on geothermal cooling using AEHE (Air Earth Heat Exchanger) with Earth pipe cooling system [24]-[30]. Another work in this di- 
rection is on Geothermal Building Cooling Systems

(http://www.climatesolver.org/innovations/living/geothermal-building-cooling-systems). Among various geothermal Cooling Systems, the system by Green India Building Systems and Services Pvt. Ltd. (GIBSS) seems to be innovative. It replaces the rejection of heat to ambient air in the conventional systems by rejection of heat to ground through piping system. But, our concept is much simpler, new and easy to implement than any of the existing geothermal cooling system.

Similarly, the same heat exchanger can also be used during winter to heat the room. For this purpose, in western and cold European countries, use the geothermal heat by drilling $100-500 \mathrm{~m}$ deep. This is very expensive. But those countries have no choice. Fortunately, in India we do have much cheaper solution. As can be seen from Figure 3 that during severe winter the temperature drops to $13^{\circ} \mathrm{C}$ during the night, while the day temperature is high and reaches up to $28^{\circ} \mathrm{C}$. In such a scenario, this high temperature of the atmosphere along with solar radiation can be harnessed using the well-known solar thermal technology during daytime. The water from the overhead tank can be connected to the solar thermal system, where the temperature reaches to $50^{\circ} \mathrm{C}-60^{\circ} \mathrm{C}$. The water reaches the sump via the heat exchanger in the room, due to gravity.

Since ours is a tropical country, most of the year we need air cooling effect. For this purpose, we can exploit the Earth property at a very shallow depth of $0-3 \mathrm{~m}$ deep. Cold countries like Europe and other countries need to use the hot condition available in the Earth at about 500 - $1000 \mathrm{~m}$ deep.

It is known from Indian Meteorological Department (IMD), Government of India at Ahmadabad that the temperature during night time ranges from $13^{\circ} \mathrm{C}-28^{\circ} \mathrm{C}$ and during day time it varies from $27^{\circ} \mathrm{C}$ to $45^{\circ} \mathrm{C}$. During January, the temperature varies from $13^{\circ} \mathrm{C}$ during night to $27^{\circ} \mathrm{C}$ during day time. In summer, it varies from $26^{\circ} \mathrm{C}$ during night to as much as $43^{\circ} \mathrm{C}$ during day time. One can harness the low temperature during night time and high temperature can be harnessed during daytime using solar thermal technology. The concept is to use the same exchanger during summer as well as winter.

\section{Methodology and Computations}

In the following, different computations and modelling results are presented. Firstly, we have computed the amount of water required to store at the roof top of the house. For this purpose, the water flow from overhead tank to the sump at a constant flow rate due to gravity need to be determined. Results are presented in Figure 4. As can be seen from the figure that about 86 litres is required if the flow rate is $1 \mathrm{cc} / \mathrm{sec}$. and 432 litres of water is required if the flow rate is $5 \mathrm{cc} / \mathrm{sec}$ and 864 litres is required if the flow rate is $10 \mathrm{cc} / \mathrm{sec}$. etc. for a 24 hour

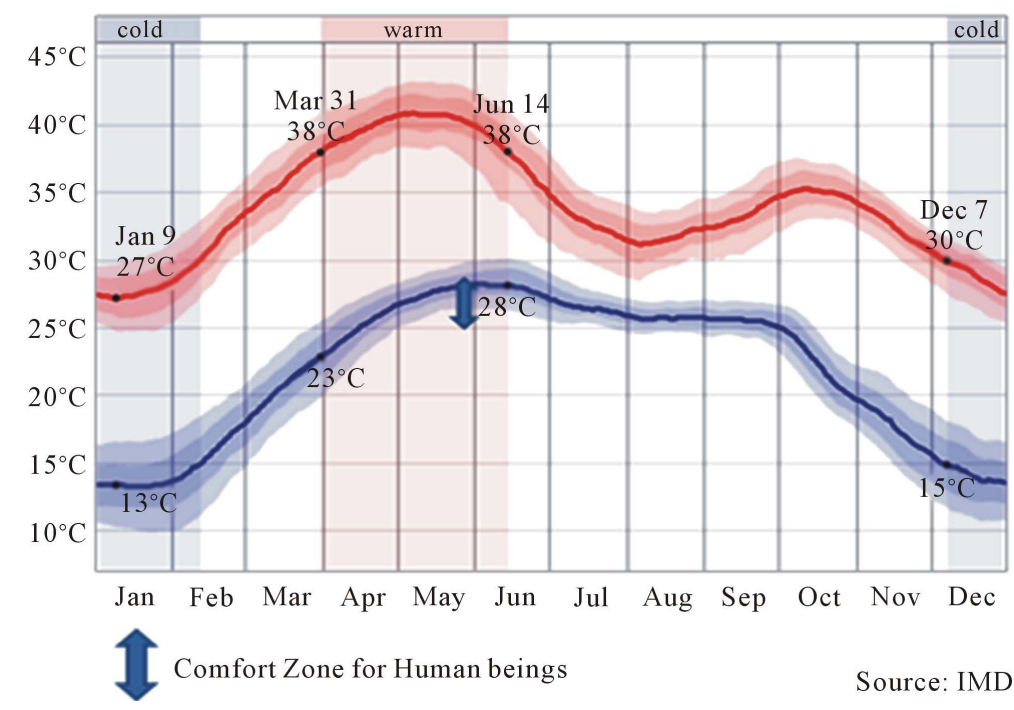

Figure 3. High and low average temperature around the year at Ahmedabad weather station. It can be seen from the data that the minimum and maximum temperature at Ahmedabad ranges from $13^{\circ} \mathrm{C}$ to $27^{\circ} \mathrm{C}$ during winter, while the maximum average temperature ranges from $28^{\circ} \mathrm{C}$ to $43^{\circ} \mathrm{C}$ during summer season (Source: Indian Meteorology Department). 


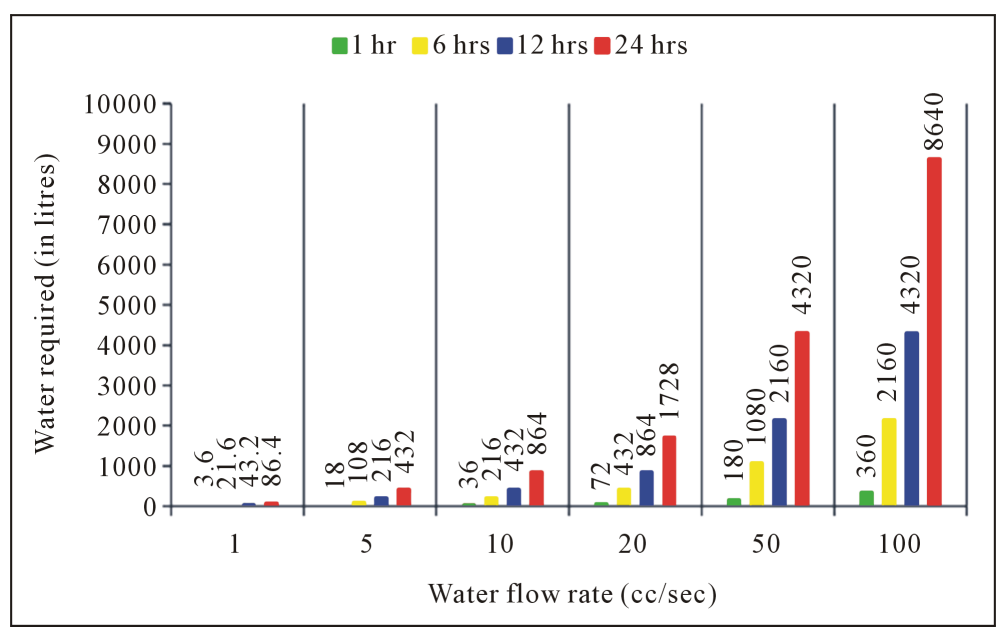

Figure 4. The quantity of water required for different outflow through heat exchanger from overhead tank to underground sump.

duration and less amount of water for less period of time of 6, 12 hours of usage etc. This is based on simple computation. It is known that $1 \mathrm{cc} / \mathrm{sec}$ corresponds to 86.4 litres of water $(1 \mathrm{X} \times 60 \mathrm{sec} 60$ minutes $\times 24$ hours $/ 1000=86.4$ litres). Thus for $100 \mathrm{cc} / \mathrm{sec}$ corresponds to 8640 litres. From this figure, one can construct on overhead tank of any shape but size depending on the usage. The water tanks are at atmospheric pressure. Dimensions of the tank required for 100, 500, 1000, 5000, 10000 litres of water capacity can be considered as per the space availability. Smaller tanks require present pumping of water from sump. Here we have considered and computed the air conditioning equipment for a room size of $3.3 \times 3.3 \times 3.3 \mathrm{~m}(10 \times 10 \times 10$ feet $)$.

A heat exchanger is used in the required space to be cooled or heated. The water is pumped from the sump to the overhead tank and passes through the heat exchanger and reaches back to sump completing a closed loop of water flow. More details about room heat exchanger is given in Section 4. The heat exchanger used in our lab experimental study is a cross counter flow cooling coil with corrugated fin single pass unit. The energy required is for water pump, a ceiling fan and optionally a fan at the heat exchanger. We have considered a height of 3 - 4 $\mathrm{m}$ and a pump of $0.25 \mathrm{HP}$ to lift water of 1000 litres from the sump. The time required to lift water to $3-4 \mathrm{~m}$ height is equal to 0.833 hours and this corresponds to 0.155 unit of electricity consumption. IT may be noted that the overhead tank is thermally insulated to prevent changes in the temperature of the water. Thus in our experiment constant temperature is maintained in the overhead tank.

From standard parameters of a popular Maruti car radiator (our heat exchanger), the energy balance equation is used to compute various thermal parameters. This is explained more clearly in a chapter on thermal design of cooling coils [31] [32].

The resultant air outlet and water outlet temperature from the tube when the fluids leave the heat exchanger can be calculated using the following equations

$$
\begin{gathered}
T w_{(i+1)}=T w_{i}+\frac{\Delta Q_{c i}}{m_{w} \times c_{p w} / 1000} \cdots \cdots \cdots \cdot \cdot\left({ }^{\circ} \mathrm{C}\right) \\
T a_{(i+1)}=T a_{i}-\frac{\Delta Q_{c i}}{m_{a} \times \frac{c_{p m}}{1000}} \cdots \cdots \cdots \cdots \cdot\left({ }^{\circ} \mathrm{C}\right)
\end{gathered}
$$

Here $T_{w(i+1)}$ is the outlet temperature of water and $T_{a(i+1)}$ is the outlet temperature of air.

Where $T a_{i}$ and $T w_{i}$ is the inlet temperature of air and water at the heat exchanger $\Delta Q_{c i}$ is the value of sensible heat transferred to the dry coil surface after $i$ loop, $c_{p m}$ is air mean specific heat in $\mathrm{KJ} / \mathrm{kgC}$ and $c_{p w}$ is water specific heat in $\mathrm{KJ} / \mathrm{kgC}$.

The outlet temperature of a single pass cross flow heat exchanger is obtained using Equations (1), (2) with $40^{\circ} \mathrm{C}$ as the ambient temperature of air inlet and the temperature of circulating water as $26^{\circ} \mathrm{C}$. The result of air outlet temperature is presented in Figure 5. 


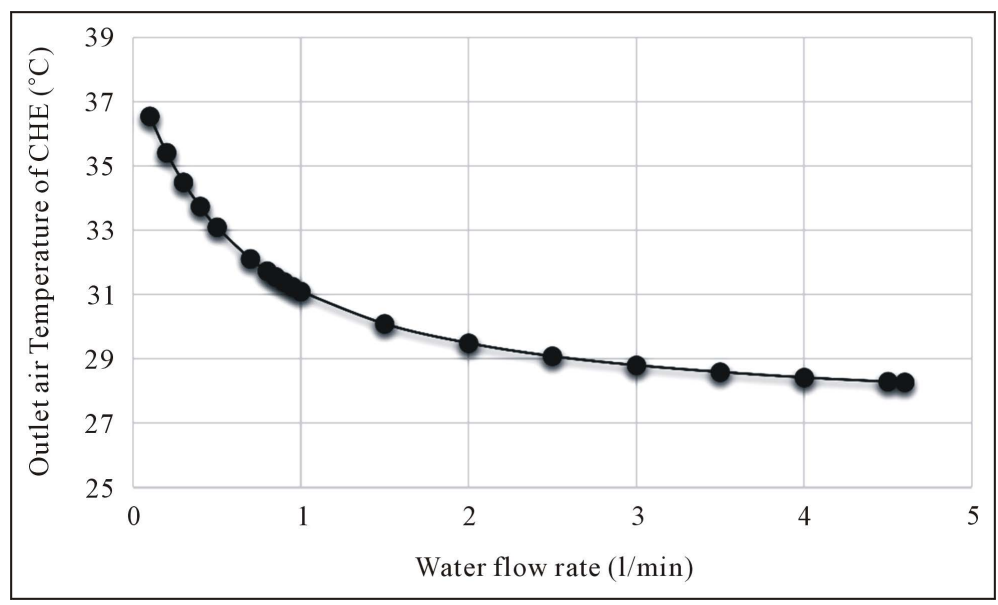

Figure 5. Outlet air temperature of compact heat exchanger at varying water flow rate when the ambient air temperature is $40^{\circ} \mathrm{C}$ and the water temperature is $26^{\circ} \mathrm{C}$.

It can be seen from the figure, as the water flow rate increases from near zero to $5 \mathrm{lit} / \mathrm{min}$, the temperature of the outlet air from the heat exchanger decreases from $37^{\circ} \mathrm{C}$ to $28^{\circ} \mathrm{C}$. It may be observed that there is no significant decrease in the outlet temperature of air beyond the water flow rate of $1.1 \mathrm{lit} / \mathrm{min}$. Accordingly, $1.5 \mathrm{lit} / \mathrm{min}$ can be considered as optimum in this case.

\section{Computational Fluid Dynamics (CFD) Modelling}

Apart from using thermal equations, we have further analysed our model (Figure 1) using CFD modelling. CFD analysis is very useful in understanding the temperature distribution in a given space with air circulation in different conditions. The air flow inside the space and heat transfer process of the system can also be studied. In our study, CFD analysis is done using Design Builder software [33]. We have considered two cases-the air flow from the heat exchanger to the space and the air circulation from ceiling fan to the space. Two models are simulated, with air, water and the room with walls. Both cold water circulation and hot water circulation are simulated in the heat exchanger.

In the first model, a $2.4 \times 2.4 \mathrm{~m}(8 \times 8$ feet $)$ screen embedded with small tubes carrying water is fixed on one side of the room as shown in a schematic diagram (Figure 6). This model has a benefit of covering large part of air inside the room. The shape of the screen resembles the letter " $\mathrm{H}$ ". It is seen from Figure 6 that the water is made to circulate through the screen through different loops and finally flow downwards by natural gravitational force as shown by arrows. The water flows and follows the screen like meandering of rivers and follows and resembles the letter "S". Thus the entire screen can be called as HS screen.

For our modelling, the screen is fixed on the southern side of the wall of the room having dimension $3.3 \times 3.3$ $\times 3.3$ cu.m $(10 \times 10 \times 10 \mathrm{cu}$. feet $)$. The screen occupies from the lower end of the wall and the extreme top portion is left uncovered. The air circulation is made through a ceiling fan. An air exhaust vent is provided at a corner of the ceiling for heat and mass balance. Figure 7 shows the result of the air movement and temperature gradient as simulated from CFD when the circulating water temperature is $26^{\circ} \mathrm{C}$.

It is observed that the temperature is cool at the southern side of the wall. The temperature gradient gradually rises from southern wall near the heat exchanger towards the northern wall. The air circulation due to fan has maintained the temperature in the centre of the room lower than the northern wall. When the circulated water is at $26^{\circ} \mathrm{C}$, maximum portion of the living space in the room is maintained at $28^{\circ} \mathrm{C}$ and the lower portion of the room is at $27^{\circ} \mathrm{C}$. Thus during summer, when outside temperature of Ahmedabad is about $40^{\circ} \mathrm{C}$ the room can be maintained at comfort level.

In winter the night temperature reaches to about $13^{\circ} \mathrm{C}$ in Ahmedabad. It is necessary to maintain the temperature inside the living space under thermal comfort zone. So the same system of heat exchanger incorporated in the room can be used for heating the space in winter. In this system, solar heater can be used to heat the water and circulate it. The CFD simulation for winter, when the ambient temperature is $13^{\circ} \mathrm{C}$ and the temperature of 


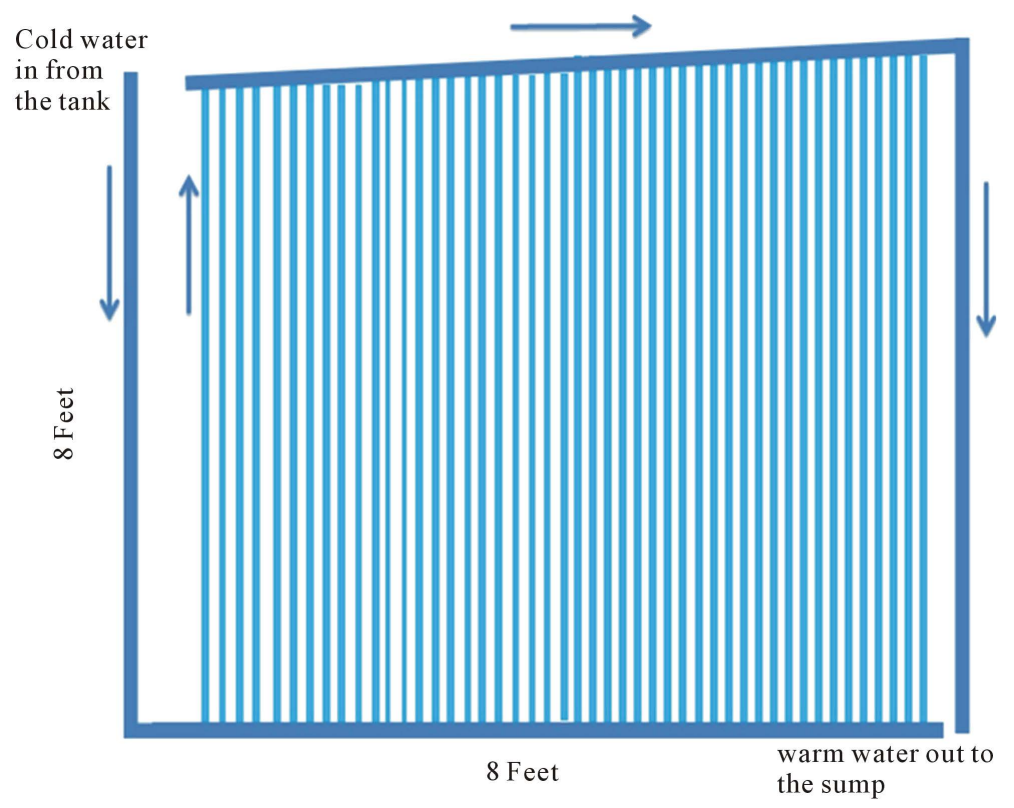

Figure 6. Schematic diagram showing the screen (HS screen) embedded with tubes with circulation of water.

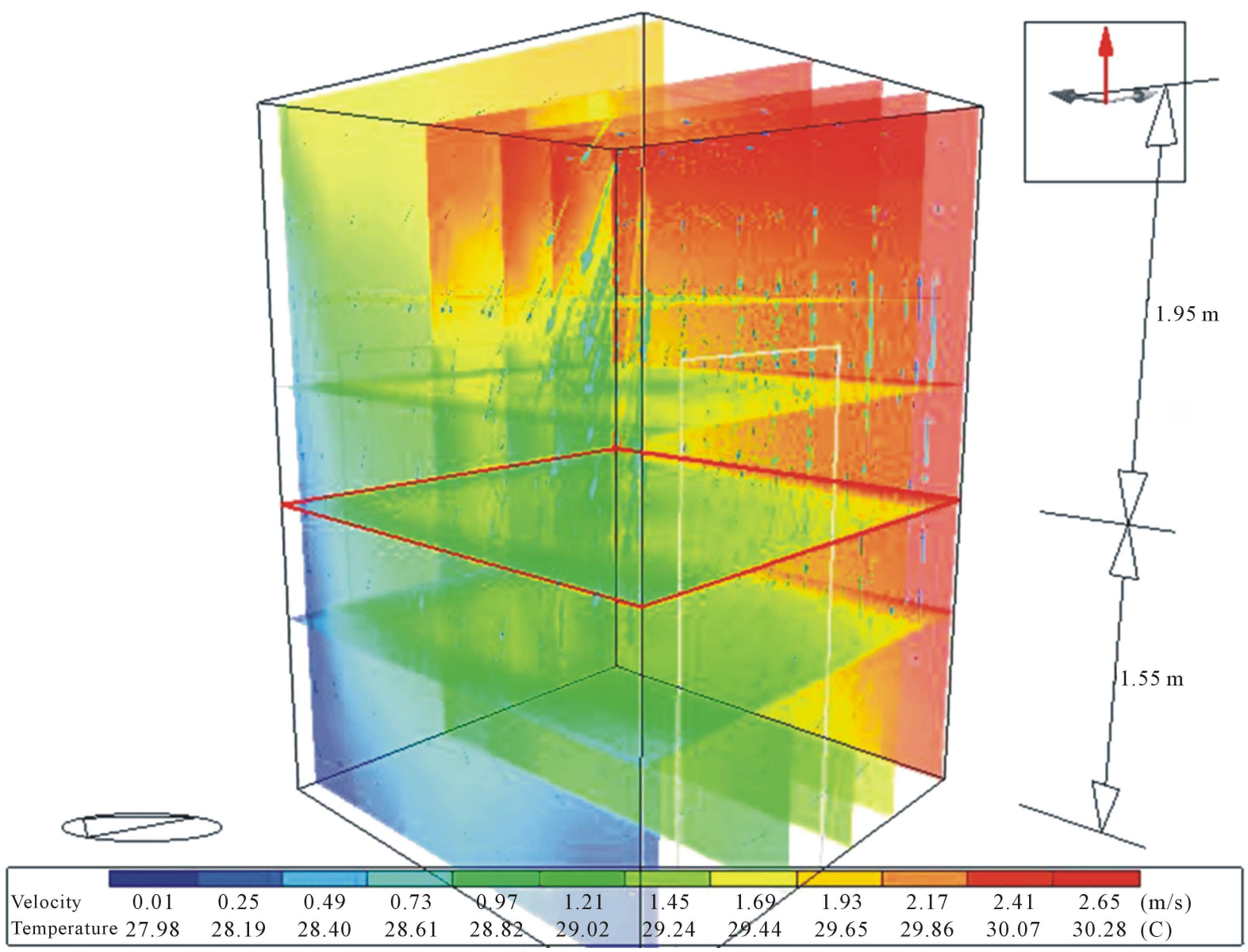

Figure 7. Sliced temperature contour of the space when a screen (heat exchanger) is attached on the southern wall and temperature of water flowing through the tubes is $26^{\circ} \mathrm{C}$ for summer condition when the water flow rate is $34 \mathrm{cc} / \mathrm{sec}$. 
circulating water is $45^{\circ} \mathrm{C}$ is shown in Figure 8. It is observed that the space is maintained at $25^{\circ} \mathrm{C}$ due to heat exchanger. The temperature increases towards the southern wall. Most of the living area is observed to be in the thermal comfort zone.

In the second model of CFD, a fan unit consisting of cooling coils with corrugated fins (similar to a car radiator) as explained earlier is modelled. Here the dimension of the heat exchanger is $1.8 \times 1.5$ feet. It is connected with overhead tank and sump as shown in Figure 9. In the model we assume that the air is flowing from the heat exchanger to the room and the air is also circulated by a ceiling fan.

The results of CFD simulation are shown in Figure 10 and Figure 11 for cooling and heating respectively. The average temperature in the living space is $27^{\circ} \mathrm{C}-28^{\circ} \mathrm{C}$ in summer from the outlet of the heat exchanger and temperature of $24^{\circ} \mathrm{C}$ in winter when the water supplied from solar water heater.

It is observed from Figure 10 and Figure 11 that the same heat exchanger can be used for heating and cooling the space by switching the cold water supply system from sump located underground as source to hot water from solar water heater located on roof top as per our requirement.

\section{Experimental Analysis}

For validation of our model and the concept, two experiments have been carried out. Initially the experiment is carried out to measure the temperature of water of the underground sump having $3 \mathrm{~h} \times 3 \mathrm{w} \times 5 \mathrm{l}$ meter dimensions. The temperature of water in the underground tank is measured using TP3001 digital thermometer and DTM 100 digital thermometer. Temperature measurements are taken at an interval of 4 hours throughout the day on 14th April 2015. A constant temperature of $27^{\circ} \mathrm{C}$ is obtained at the surface of water of the underground sump and

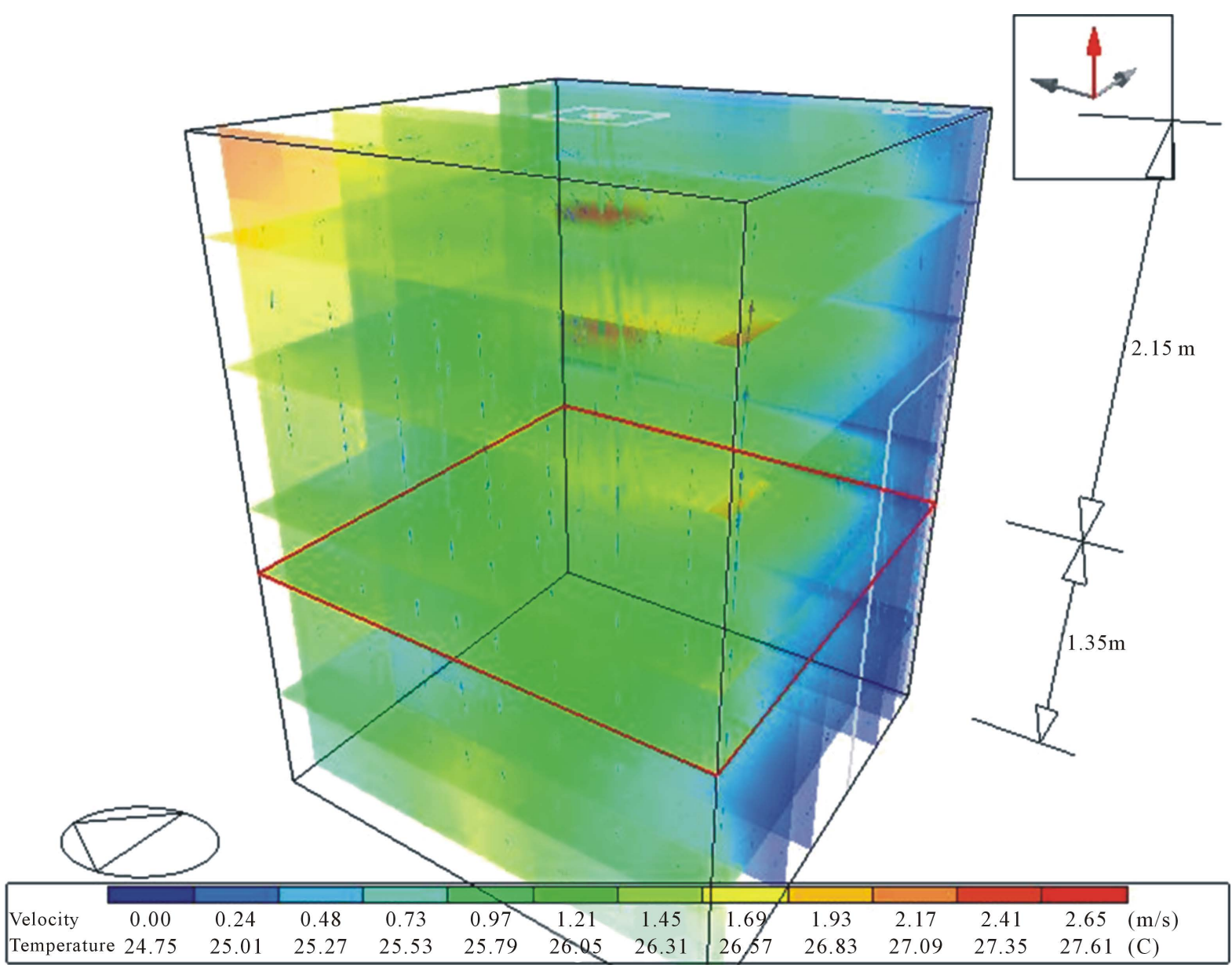

Figure 8. Sliced temperature contour of the space when the heat exchanger (screen) is attached on the southern wall and temperature of water flow through the tubes is $45^{\circ} \mathrm{C}$ for winter condition when the water flow rate is $34 \mathrm{cc} / \mathrm{sec}$. 


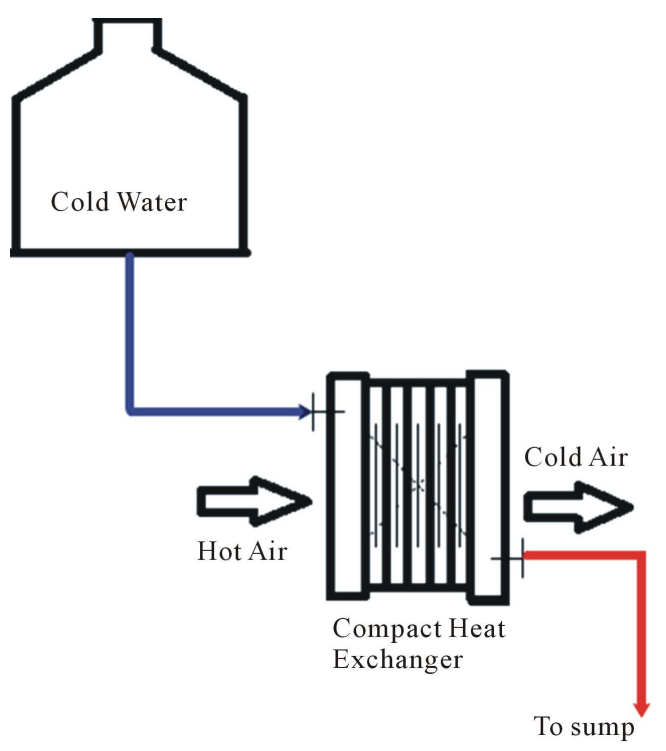

Figure 9. Water flow pattern from overhead tank through compact heat exchanger and back to sump due to natural gravity for heating/cooling the space as modelled in CFD.

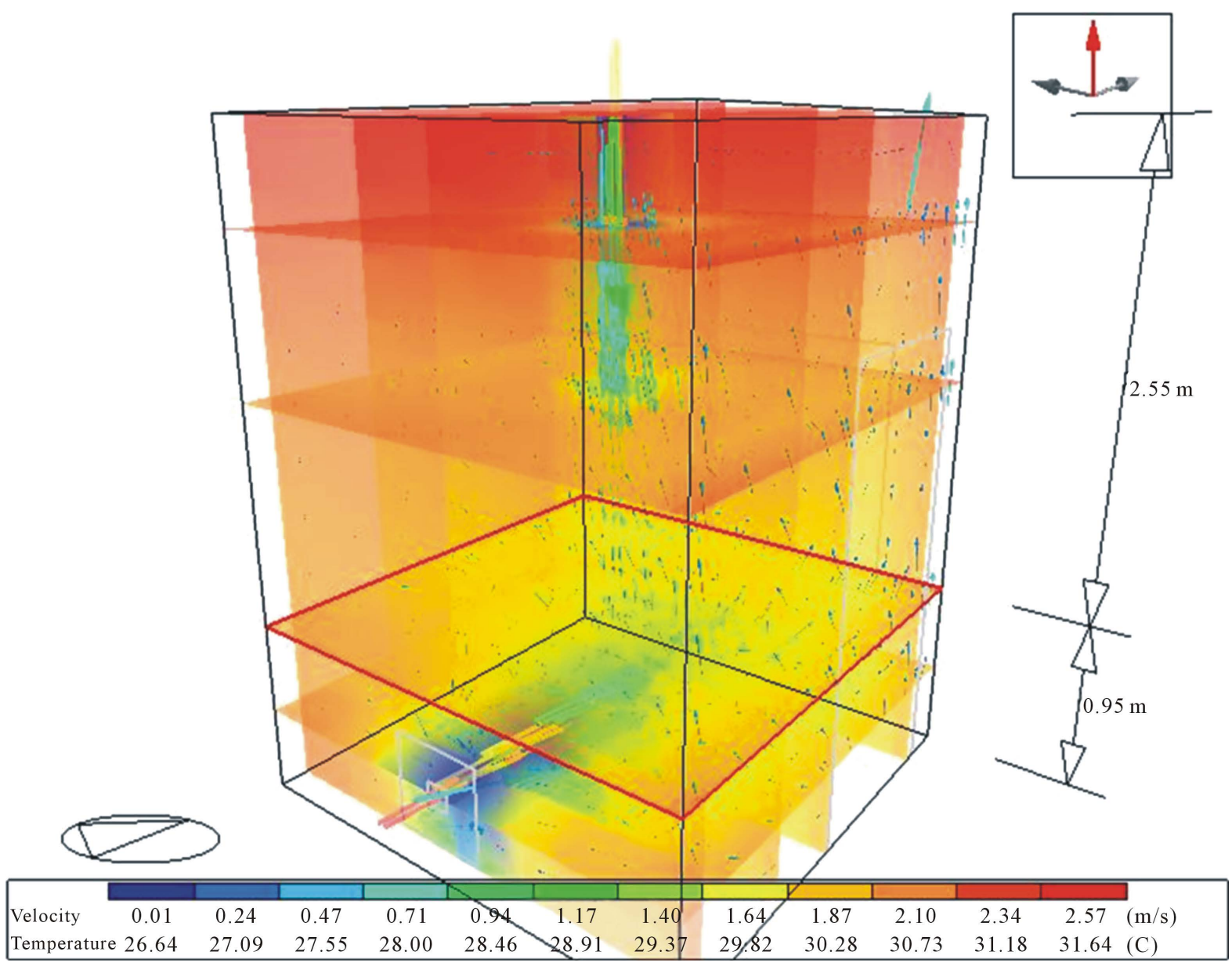

Figure 10. Sliced temperature contour of the space when a compact heat exchanger is placed inside the room and water of $26^{\circ} \mathrm{C}$ is allowed to flow at a speed of $34 \mathrm{cc} / \mathrm{sec}$. 


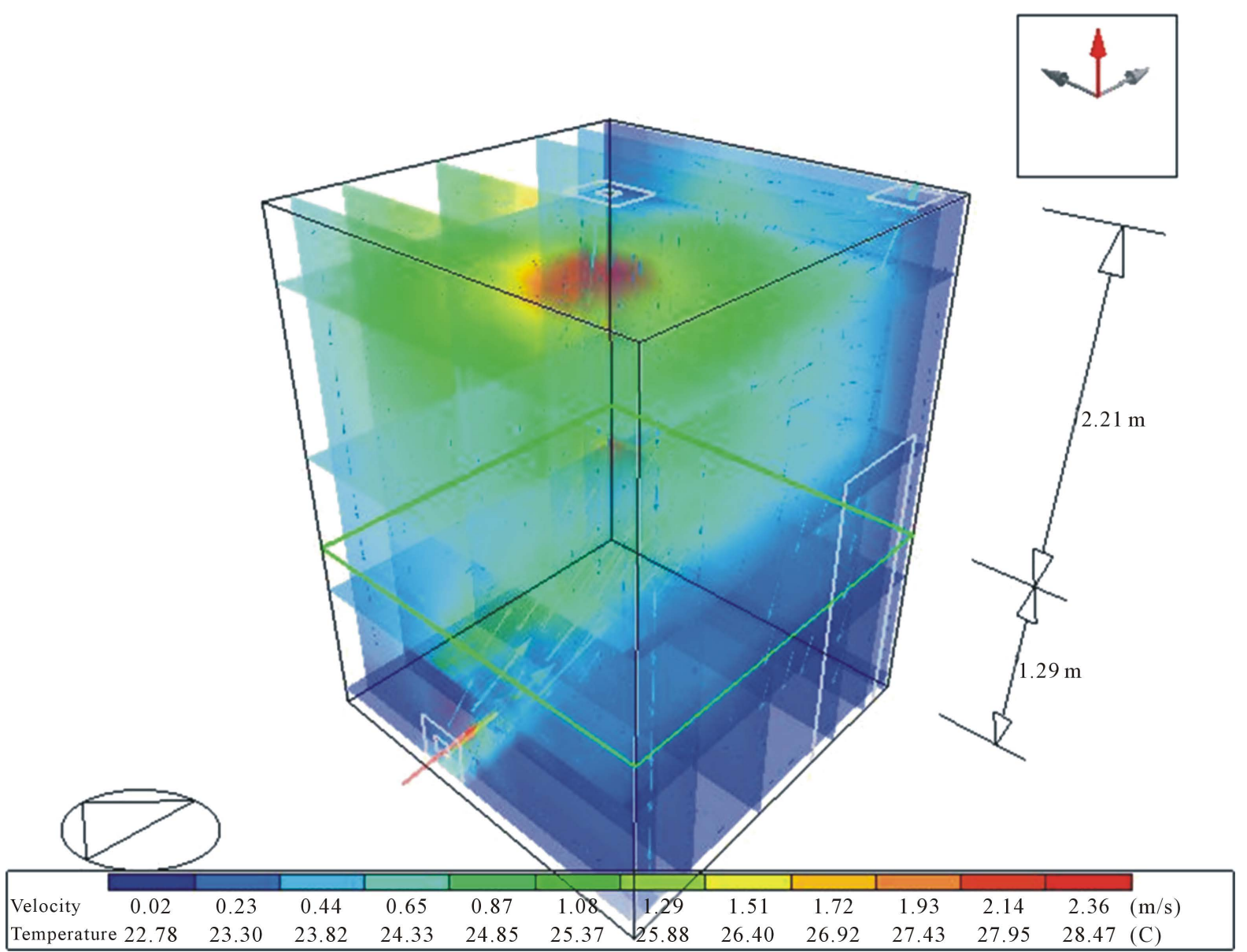

Figure 11. Sliced temperature contour of the space when a compact heat exchanger is placed inside the room and water of $45^{\circ} \mathrm{C}$ is allowed to flow at a speed of $34 \mathrm{cc} / \mathrm{sec}$.

$26^{\circ} \mathrm{C}$ at a depth of $3 \mathrm{~m}$. The outside ambient temperature varies from $28^{\circ} \mathrm{C}$ in the morning to $34^{\circ} \mathrm{C}$ in the afternoon.

Second experiment has been carried out using earth-water heat exchanger on 26th April 2015. For this purpose the security cabin office space of Pandit Deendayal Petroleum University is used. The room floor area is 10 $\times 10$ feet with a height of 12 feet. As described before in our model the water is pumped from underground sump to the overhead tank. Through natural gravity the water reaches the sump through heat exchanger. For experimental purpose, the overhead tank is simulated with a small steel tank connected with a valve to control the water flow rate. Water at $26^{\circ} \mathrm{C}$ also flows through a compact heat exchanger. The steel tank is kept on a table to maintain the higher potential energy of water to maintain the natural flow by gravity through the heat exchanger. The ambient temperature is noted as $43^{\circ} \mathrm{C}$ and relative humidity as $10 \%$ by a digital thermometer and hygrometer HTC-1. To reduce the room temperature effectively, an additional arrangement of two heat exchangers are enclosed. Only one exhaust fan is made operative to save power. Water is allowed to flow through all the three heat exchangers. The main compact heat exchanger is operated by an APT43 SMPS 12V @10 ampere kit to maintain continuous power supply to the unit. Our experimental arrangement is shown in Figure 12. Although this experiment cannot be directly depicts the proposed model, it provide an insight to achieve the result.

Water temperature is maintained at $26^{\circ} \mathrm{C}$ and stored in the steel tank. The water circulated through the heat exchanger unit is collected outside in a separate tank. When the valve is opened, water is initially circulated through the front heat exchanger at a speed of $17 \mathrm{cc} / \mathrm{sec}$ and later at $34 \mathrm{cc} / \mathrm{sec}$. In both the cases, the ambient temperature is $43^{\circ} \mathrm{C}$.

Figure 13 and Figure 14 are thermal images of the heat exchanger taken using Fluke thermal imager. It is observed that as the water flow rate increases, the distribution of water in the tube is improved and the cooling 


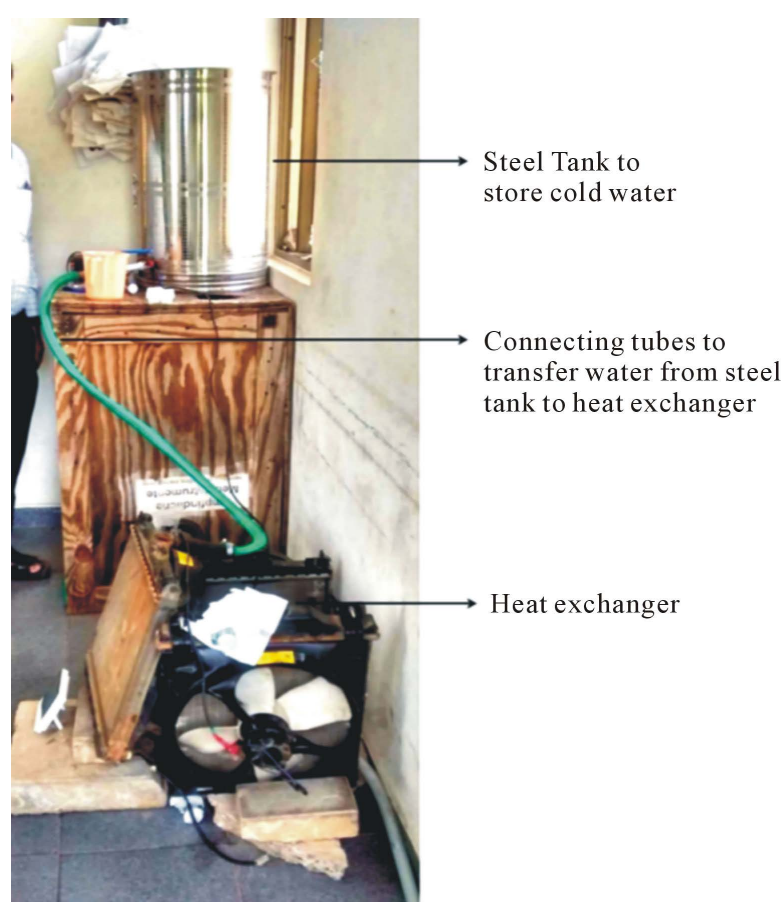

Figure 12. Experimental setup at Pandit Deendayal University Campus. Steel drum is assumed as water tank at high level. Water passes through the green tube and reaches the heat exchanger.

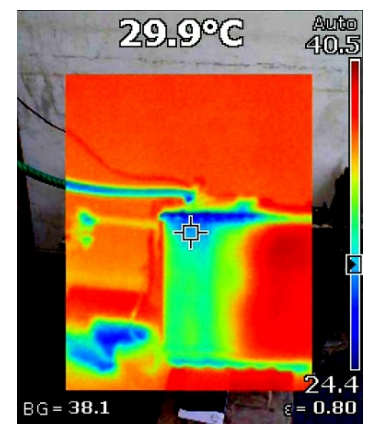

Figure 13. Thermal image of enclosed system with water flow rate of $17 \mathrm{cc} / \mathrm{sec}$ using FLUKE THERMAL IMAGER Ti105 after 15 minutes of operation.

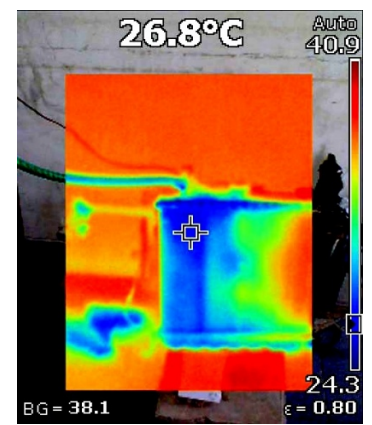

Figure 14. Thermal image of enclosed system with water flow rate of $34 \mathrm{cc} / \mathrm{sec}$ using FLUKE THERMAL IMAGER Ti105 after 15 minutes of operation. 
effect is also improved. It is evident that as the water flow rate increases, the outlet temperature of air from heat exchanger decreases. The results are matching with the mathematical modelling results as it can be seen from Figure 5 that for $17 \mathrm{cc} / \mathrm{sec}(1.02 \mathrm{l} / \mathrm{min})$ the outlet temperature is $30^{\circ} \mathrm{C}$ and our experiment has also shown the temperature of $29.9^{\circ} \mathrm{C}$. The experimental results are tabulated below (Table 3 ).

\section{Summary and Conclusions}

We have suggested innovative ways to control the temperature of the space in a room. Most of the year in a tropical country like India, we require space cooling. It is shown here that using geothermal cooling system one can effectively cool the space with low energy. In a hot country like India, two months in a year, we may require space heating. It is shown here that water from the solar heater can be used in the heat exchanger to increase the temperature of the room during severe winter in Gujarat. Although similar concepts of geothermal cooling are reported in the literature, using Air Earth Tube heat exchanger system, our concept is new and requires minimum changes in the existing system in the house as compared to earlier suggested systems. We demonstrate that underground water sump can be pumped to the higher elevation and this cold water, acquires heat from the heat exchanger and reaches the sump again by gravity without using any artificial energy. Normal ceiling fan will help to circulate the cooled air in the room. This way, the energy needed for air-conditioning system in the room reduces by about 5 times compared to the conventional system of Air Conditioner equipment.

The first key finding of the study is that the underground water is maintained at a constant temperature of $26^{\circ} \mathrm{C}$ with respect to different ambient temperatures in Ahmedabad region even during hot summer season. It is suitable to implement earth water heat exchanger in Ahmedabad for cooling. The modelling and experimental results (Table 3) have shown significant temperature reduction at the heat exchanger outlet with respect to the ambient temperature. Unlike Air-Earth tube heat exchangers, in our model, air quality is maintained at the same level as we are using water as a fluid to transport heat. This is due to the fact that the moisture content increases in earlier proposed models as air flows through the underground pipes. But the use of compact heat exchanger in our study eliminates that problem. Additionally, the power consumption is significantly reduced in our study.

A 1.5 TR air conditioner unit has the power rating of 1400 Watts. Thus for one hour operation, it consumes 1.4 units of electrical power. In our model, in the first case of heat exchanger screen, the power consuming elements are a pump and a ceiling fan. If we consider cold water circulation as $34 \mathrm{cc} / \mathrm{sec}$, then 1000 litres of water will last for 8 hours. Power required to pump 1000 litres of water using $0.25 \mathrm{HP}$ pump is 0.155 units and the power for the fan ( 40 Watts) for 1 hour corresponds to 0.04 units). Thus, the total electricity consumption for one hour operation of fan and pump for 1000 litres of water is 0.195 units. In second case, a compact heat exchanger with a fan is used. The total consumption in this case is equal to 0.235 unit ( 0.24 unit approximately) as 0.155 for pump 0.04 for ceiling fan and 0.04 for heat exchanger fan. Thus as compared to air conditioning unit, our concept in both the cases is much energy efficient. The only disadvantage of our system is one need to wait for at least 1 hour to reach the comfort zone, where as the powerful conventional AC may bring the room to comfort level within a short period of 5 to 10 minutes. This is not a great disadvantage if one plans to use the room in advance and operate accordingly.

Thus the present system of geothermal cooling and solar heating through heat changer in a room are new concepts with water circulation. This is more energy efficient system as compared to the existing electrical air condition system. Our concept, if implemented in Gujarat on most of the houses, bungalows, large space usage locations such as cinema halls, malls, auditoriums, etc., large electricity can be saved. Implementation of our concept is simple and cost effective. We sincerely hope that new entrepreneurs and MSME's may take up this concept on all India basis and implement the same effectively. Our concept if implemented properly not only generate employment but follows the "Make in India" path apart from energy saving. This new concept and details given in the present paper has also been filed for a patent (vide patent application No. 4574/MUM/2015).

Table 3. Experimental results for different water flow rates through heat exchanger.

\begin{tabular}{ccc}
\hline Sr. No. & Water flow rate $(\mathrm{cc} / \mathrm{sec})$ & Temperature of air $\left({ }^{\circ} \mathrm{C}\right)$ \\
\hline 1 & 17 & 29.9 \\
2 & 34 & 26.8 \\
\hline
\end{tabular}




\section{Acknowledgements}

The authors would like to thank Shri D.J. Pandian, Chairman, GERMI for his continuous encouragement of our research project. Discussions with Dr. Sagarkumar Agravat is highly appreciated. We also thank all GERMI staff and administration for extending their help in various ways during the execution of the project. The second author thanks the Director GERMI for providing the scholarship and help to complete the project. We also would like to thank School of Technology (SOT), PDPU authorities for providing necessary help, coordination with equipment for conducting our experimental setup.

\section{References}

[1] Dudhani, S. and Sinha, A. (2006) Renewable Energy Sources for Peak Load Demand Management in India. International Journal of Electrical Power and Energy Systems, 28, 396-400. http://dx.doi.org/10.1016/j.ijepes.2005.12.011

[2] Harinarayana, T. (2015) An Innovative Solution for Power Problem in India. 10th National Conference on Indian Energy Sector, Ahmedabad, Synergy with Energy, Ahmedabad, 5-6 May 2015, 7-11.

[3] Mittal, P. (2015) Wireless Electricity Billing Cum Theft Detection System. International Research Journal of Engineering and Technology (IRJET), 2, 83-86.

[4] Arasu, J.G. (2008) Globalization and Infrastructural Development in India. Atlantic Publishers \& Distributors(p) Ltd., New Delhi.

[5] Pawar, R. and Singh, J. (2012) Calculation of T\&D Loss \% Based on 11/0.4 KV Substation in a Distribution Utility. 2012 IEEE 5th Power India Conference, 19-22 December 2012, Murthal.

[6] Fanger, P.O. (1970) Thermal Comfort. McGraw-Hill, Denmark.

[7] ASHRAE (2004) ASHRAE Standard 55: Thermal Environmental Conditions for Human Occupancy. American Society of Heating Refrigerating and Air-Conditioning Engineers, Atlanta.

[8] Szokolay, S.V. (2004) Introduction to Architectural Science: The Basis of Sustainable Design. Architectural Press, Oxford.

[9] Sharan, G. and Jadhav, R. (2002) Soil Temperature Regime at Ahmedabad. Journal of Agricultural Engineering, 39, 1.

[10] Sodha, M.S., Sharma, A.K., Singh, S.P., Bansal, N.K. and Kumar, A. (1985) Evaluation of an Earth-Air Tunnel System for Cooling/Heating of a Hospital Complex. Building and Environment, 20, 115-122.

[11] Georgios, F. and Soteris, K. (2007) Ground Heat Exchanger-A Review of Systems, Models and Applications. Renewable Energy, 32, 2461-2478.

[12] Chel, A. and Tiwari, G.N. (2010) Stand-Alone Photovoltaic (PV) Integrated with Earth to Air Heat Exchanger (EAHE) for Space Heating/Cooling of Adobe House in New Delhi. Energy Conversion and Management, 51, 393-409. http://dx.doi.org/10.1016/j.enconman.2009.10.001

[13] Kumar, R., Ramesh, S. and Kaushik, S.C. (2003) Performance Evaluation and Energy Conservation Potential of EarthAir-Pipe System Coupled with Non-Air-Conditioned Building. Building and Environment, 38, 807-813. http://dx.doi.org/10.1016/S0360-1323(03)00024-6

[14] Maerefat, M. and Haghighi, A.P. (2010) Passive Cooling of Buildings by Using Integrated Earth to Air Heat Exchanger and Solar Chimney. Renewable Energy, 35, 2316-2324. http://dx.doi.org/10.1016/j.renene.2010.03.003

[15] Mihalakakou, G., Santamouris, M., Asimakopoulos, D. and Tselepidaki, I. (1995) Parametric Prediction of the Buried Pipes Cooling Potential for Passive Cooling Applications. Solar Energy, 55, 163-173. http://dx.doi.org/10.1016/0038-092X(95)00045-S

[16] Bansal, V., Misra, R., Agrawal, G.D. and Mathur, J. (2009) Performance Analysis of Earth-Pipe-Air Heat Exchanger for Winter Heating. Energy and Buildings, 41, 1151-1154. http://dx.doi.org/10.1016/j.enbuild.2009.05.010

[17] Bansal, V., Misra, R., Agrawal, G.D. and Mathur, J. (2010) Performance Analysis of Earth-Pipe-Air Heat Exchanger for Summer Cooling. Energy and Buildings, 42, 645-648. http://dx.doi.org/10.1016/j.enbuild.2009.11.001

[18] Ghosal, M.K., Tiwari, G.N., Das, D.K. and Pandey, K.P. (2005) Modeling and Comparative Thermal Performance of Ground Air Collector and Earth Air Heat Exchanger for Heating of Greenhouse. Energy and Buildings, 37, 613-621. http://dx.doi.org/10.1016/j.enbuild.2004.09.004

[19] De Paepe, M. and Janssens, A. (2003) Thermo-Hydraulic Design of Earth-Air Heat Exchangers. Energy and Buildings, 35, 389-397. http://dx.doi.org/10.1016/S0378-7788(02)00113-5

[20] Givoni, B. (1994) Passive and Low Energy Cooling of Buildings. John Wiley and Sons, Inc., Toronto.

[21] Ozgener, L. (2011) A Review on the Experimental and Analytical Analysis of Earth to Air Heat Exchanger (EAHE) Systems in Turkey. Renewable and Sustainable Energy Reviews, 15, 4483-4490. 
http://dx.doi.org/10.1016/j.rser.2011.07.103

[22] Goswami, D.Y. and Ileslamlou, S. (1990) Performance Analysis of a Closed Loop Climate Control System Using Underground Air Tunnel. Journal of Solar Energy Engineering, 112, 76-81. http://dx.doi.org/10.1115/1.2929650

[23] Bansal, V. and Mathur, J. (2009) Performance Enhancement of Earth Air Tunnel Heat Exchanger Using Evaporative Cooling. International Journal of Low-Carbon Technologies, 4, 150-158. http://dx.doi.org/10.1093/ijlct/ctp017

[24] Ghosal, M.K. and Tiwari, G.N. (2006) Modelling and Parametric Studies for Thermal Performance of an Earth to Air Heat Exchanger Integrated with a Greenhouse. Energy Conversion and Management, 47, 1779-1798. http://dx.doi.org/10.1016/j.enconman.2005.10.001

[25] Givoni, B. (2007) Cooled Soil as a Cooling Source for Buildings. Solar Energy, 81, 316-328. http://dx.doi.org/10.1016/j.solener.2006.07.004

[26] Sharan, G. and Jadhav, R. (2003) Performance of Single Pass Earth-Tube Heat Exchanger: An Experimental Study. Journal of Agricultural Engineering, 40, 1-8.

[27] Goswami, D.Y. and Biseli, K.M. (1993) Use of Underground Air Tunnels for Heating and Cooling Agricultural and Residential Buildings. Fact Sheet EES 78, Florida Energy Extension Service, University of Florida, Gainesville, 1-4.

[28] Hanby, V.I., Loveday, D.L. and Al-Ajmi, L. (2005) The Optimal Design for a Ground Cooling Tube in a Hot, Arid Climate. Building Services Engineering Research \& Technology, 26, 1-10. http://dx.doi.org/10.1191/0143624405bt114oa

[29] Lee, K.H. and Strand, R.K. (2008) The Cooling and Heating Potential of an Earth Tube System in Buildings. Energy and Buildings, 40, 486-494. http://dx.doi.org/10.1016/j.enbuild.2007.04.003

[30] Inalli, M. and Esen, H. (2004) Experimental Thermal Performance Evaluation of a Horizontal Ground-Source Heat Pump System. Applied Thermal Engineering, 24, 2219-2232. http://dx.doi.org/10.1016/j.applthermaleng.2004.01.005

[31] http://cdn.intechopen.com/pdfs-wm/30773.pdf.

[32] Tamm, H. and Green, G.H. (1973) Experimental Multi-Row Crossflow Heat Exchanger Dynamics. ASHRAE Transactions, 79, 9-18.

[33] Eastman, C., Teicholz, P., Sacks, R. and Liston, K. (2008) BIM Handbook: A Guide to Building Information Modeling for Owners, Managers, Designers, Engineers and Contractors. John Wiley \& Sons, Hoboken, 1-485. 